TERMINUS

t. 22 (2020)

z. 4 (57)

s. 333-355

www.ejournals.eu/

Terminus

\title{
Oda (IV 30) Macieja Kazimierza Sarbiewskiego do Janusza Skumina Tyszkiewicza
}

\section{Abstract \\ At Heaven's Gate: Maciej Kazimierz Sarbiewski's Ode (IV 30) to Janusz Skumin Tyszkiewicz}

The main purpose of this paper is twofold. Firstly, it presents the edition of a Latin ode written by Maciej Kazimierz Sarbiewski SJ (1595-1640) dedicated to Janusz Skumin Tyszkiewicz (1572-1642), Voivode of Trakai, after the death of his beloved wife, Barbara née Naruszewicz (1580-1627). A new Polish translation of this text and a commentary are also provided. Secondly, the first part of the paper, or the invitation to close reading, aims at giving more detailed information about the rhetorical architecture of the ode, particularly its composition, arguments, and figures.

Sarbiewski, regarded as the most brilliant imitator of Horatian lyrical discourse in early-modern Europe ("Christian Horace"), used the established schemes and formulas to create a Christian consolation based on reinventing the lyrical arguments. The persuasive power of his ode is strongly related to vivid, evocative, and meaningful images. The correlation between divine inspiration and poetic perfection allowed him to refashion the rhetorical patterns of epicedium. Sarbiewski wanted to demonstrate his ability to use various modes of linguistic expression. Thus, in the heart of his consolation there is a story about "the cracks" (rimae) in heaven's gate and a poet who can take a short glimpse into "the heavenly city" (urbs caelestis).

The consolation is to confirm the belief that, following departure, a deceased can live in the realm of eternal joy and happiness. Paradoxically, he or she can be happier there than during his or her earthly life. Despite its rhetorical refinement and poetical elaboration, it always serves the same purpose. Moreover, its realisation only becomes possible due to literary mediation. The poet appears to be the mediator between the world of the living and the world of the dead. The final verses of the poem bring a moral lesson best epitomized in a brief appeal "do not want more" (nec tu plura velis), addressed not only to Tyszkiewicz, but also to the poet himself and the readers.

doi:10.4467/20843844TE.20.018.12538

\section{Keywords}

Maciej Kazimierz

Sarbiewski

(Sarbievius), Janusz Skumin Tyszkiewicz, consolation, epicedium 
Konsolacja, niezależnie od tego, czy przyjmuje postać długiej mowy czy lirycznej pieśni, krąży wokół utartych, stałych motywów, wyobrażeń, argumentów, obrazów i formuł. Niektóre z nich funkcjonują niemal jak poetyckie zaklęcia, powtarzane w niezmienionej albo niewiele zmienionej formie przez stulecia. Silna konwencjonalizacja odebrała części z nich językową świeżość, ale nie pozbawiła ich całkowicie walorów perswazyjnych. Z retorycznego punktu widzenia najbardziej przekonująca konsolacja służy utwierdzeniu adresata (odbiorców) w przekonaniu, że zmarły ma się jeszcze lepiej niż za życia; że paradoksalnie dopiero teraz cieszy się pełnią istnienia. Ważną rolę odgrywa tu motyw przywołania danej postaci z zaświatów, tylko po to, aby osobiście zaświadczyła o pośmiertnej szczęśliwości. Staje się to możliwe dzięki literackiej mediacji. Poeta okazuje się bowiem pośrednikiem między światem żyjących a krainą zmarłych. Jego onirycznym wizjom, argumentom i obrazom zawdzięczają oni poetycką nieśmiertelność.

Retoryka konsolacji, przydatna w tworzeniu prawdopodobnej argumentacji i wizji lirycznej, kształtuje pieśń Macieja Kazimierza Sarbiewskiego skierowaną do Janusza Skumina Tyszkiewicza po śmierci jego żony, Barbary z Naruszewiczów (IV 30) ${ }^{\mathbf{1}}$. Głównym celem tego szkicu interpretacyjnego jest wprowadzenie (zaproszenie) do lektury ody adresowanej do Tyszkiewicza, a także jej edycja krytyczna, opatrzona nowym przekładem i niezbędnymi komentarzami rejestrującymi nawiązania do wcześniejszej literatury ${ }^{2}$. Twórczość Sarbiewskiego była analizowana najczęściej w dotychczasowych badaniach w perspektywie imitacji (emulacji) antycznych wzorców czerpanych głównie z liryki Horacego (parodia horacjańska) ${ }^{3}$, a także Wergiliusza i Owidiusza. Interesujące może się jednak okazać uzupełnienie tych interpretacji o uważne śledzenie przekształceń pewnych motywów czy obrazów, na przykład toposów czy motywów epicedialnych, w poezji Sarbiewskiego traktowanej jako w pełni autonomiczny „dyskurs liryczny”4. Do niektórych z nich poeta

$1 \quad$ Pieśń Sarbiewskiego tłumaczył Adam Naruszewicz: Oda Sarbiewskiego do Janusza Skumina Tyszkiewicza, wojewody trockiego, w dzień pogrzebu swojej matżonki, „Zabawy Przyjemne i Pożyteczne” 5 (1772), cz. 2, s. 401-405; por. G. Wichary, Recepcja twórczości M.K. Sarbiewskiego w polskim Oświeceniu, „Pamiętnik Literacki” 66 (1975), z. 2, s. 147.

2 Podstawa edycji: M.C. Sarbievius, Lyricorum libri quattuor, epodon liber unus alterque epigrammatum, Antwerpen: Officina Plantiniana Balthasaris Moreti, 1634; dalej cytuję ten zbiór jako: Sarbievius 1634. Wszystkie cytaty z pieśni Sarbiewskiego podaję za tym wydaniem. Tłumaczenia, o ile nie zaznaczono inaczej, pochodzą ode mnie. Cytaty z Pisma Świętego podaję za edycją: Pismo Święte Starego i Nowego Testamentu w przekładzie z języków oryginalnych [Biblia Tysiąclecia], oprac. zespół biblistów polskich z inicjatywy benedyktynów tynieckich, wyd. 5, Poznań 1999.

3 Por. wybrane opracowania: J. Budzyński, „Parodia” $i$ „palinodia” horacjańska w liryce M.K. Sarbiewskiego. Studium z techniki poezji barokowej, „Meander” 30 (1975), s. 88-108; K. Stawecka, Maciej Kazimierz Sarbiewski - prozaik i poeta, Lublin 1989; A.W. Mikołajczak, Antyk w twórczości Macieja Kazimierza Sarbiewskiego, Poznań 1994; P. Urbański, Theologia fabulosa. Commentationes Sarbievianae, Szczecin 2000; E. Buszewicz, Sarmacki Horacy i jego liryka. Imitacja - gatunek - styl. Rzecz o poezji Macieja Kazimierza Sarbiewskiego, Kraków 2006; M. Łukaszewicz-Chantry, Trzy nieba. Przestrzeń sakralna w liryce Macieja Kazimierza Sarbiewskiego, Wrocław 2002.

$4 \quad$ Pojęciem tym posługuję się w znaczeniu, jakie nadał mu Gregson Davis w książce Polyhymnia: The Rhetoric of Horatian Lyric Discourse (Berkeley 1991, s. 9-10). Ujmuje ono twórczość Horacego całościowo 
wielokrotnie powracał w swoich odach, opracowując je niejako na nowo, nadając im za każdym razem nieco inne znaczenia.

Barbara była córką Stanisława Naruszewicza herbu Wadwicz (zm. 1589), kasztelana smoleńskiego (1588-1589), i jego pierwszej żony, Elżbiety (Halszki) Komajewskiej. Urodziła się w 1580 roku. W wieku piętnastu lat wyszła za mąż za Janusza Skumina Tyszkiewicza herbu Leliwa (1572-1642), syna Teodora Tyszkiewicza i Katarzyny Lackiej, pisarza wielkiego litewskiego (1607), wojewodę trockiego (16261640), a następnie wileńskiego (1640-1642) ${ }^{5}$. Owocem tego małżeństwa była jedna córka, Katarzyna Eugenia (ok. 1610-1646). Jej zaręczyny (7 maja 1620) z dworzaninem królewskim Janem Wojciechem Rakowskim (ok. 1594-1639), późniejszym wojewodą witebskim, zostały z nieznanych powodów zerwane ${ }^{6}$. Siedem lat później poślubiła księcia Janusza Wiśniowieckiego herbu Korybut (1599-1636), starostę krzemienieckiego, koniuszego wielkiego koronnego, najstarszego syna Konstantego Wiśniowieckiego i Anny Zahorowskiej. Ceremonia ślubna odbyła się 19 września 1627 roku w Wilnie. Barbara zmarła nagle w czasie przygotowań do uroczystości weselnych córki 18 lipca 1627 roku w Dzitwie w powiecie lidzkim. Z powodu śmierci matki panny młodej wesele miało skromny charakter.

Pogrzeb Barbary z Naruszewiczów odbył się 2 września 1627 roku. Została pochowana w kaplicy Zwiastowania NMP ufundowanej przez męża (zwanej później kaplicą Tyszkiewiczów) przy wileńskiej cerkwi św. Trójcy. Kazanie pogrzebowe wygłosił Jan Dubowicz (zm. 1646) z klasztoru bazylianów, który połączył we wstępie tej oracji obraz potoku łez wylewanych nad zmarłą z metaforą strumienia wymowy:

O, kiedy by wzdychania piersi mogły się obrócić w krasomówstwo języka, jako naczynia oddychania obracają się w dźwięk, życzyłbym, aby wzdychania was wszytkich zgromadziły się w piersi moje, gdy mi jednemu za wszytkie, jednemu przed wszytkiemi przychodzi mówić; pragnąłbym, aby rzeka łez, wynikając z oczu moich i waszych, obróciła się w rzekę krasomówstwa z ust moich wypływajacą. Płakać dziś będziemy, iż ustała światłość jej; wszakże przy tym płaczu będziemy słuchać Ducha Świętego upominającego i przestrzegającego nas: Modicum plora super mortuum, quoniam requievit. „Nad umarłym mało płacz, abowiem odpoczął” [Syr 22,11 - W.R.]. Przybądź, nasłodszy Jezu, jedyna nadziejo i pociecho

jako wypowiedź perswazyjną złożoną z takich elementów retorycznych, jak: toposy, argumenty, tropy i figury.

5 Por. M. Kuran, Mecenat kulturalny Janusza Skumina Tyszkiewicza. Aspekt wizualny druków naukowych i okolicznościowych, „Dailes Istorijos Studijos” 4 (2010), s. 69-104; idem, Obraz i słowo w kazaniu Aleksandra Dubowicza pod tytułem Wyprawienie osoby... upamiętniającym postać Janusza Skumina Tyszkiewicza, „Terminus” 14 (2012), z. 25, s. 119-135.

$6 \quad$ Zaręczyny upamiętnił druk okolicznościowy Eustachego Droczyłowskiego, Dextera. Fidei constantiaeque testis [...], Vilnius, Typis Academicis Societatis Iesu, 1620; por. M. Kuran, Druk Eustachego Droczyłowskiego z okazji zaręczyn Rakowskiego i Tyszkiewiczówny (U genezy „Księcia Wiśniowieckiego Janusza” Samuela Twardowskiego), „Akapit. Rocznik Towarzystwa Bibliofilów Polskich w Warszawie” 1 (2006), s. 11-20. 
tej zmarłej, gdy w żywocie była, do tej gromady; przybądź, który ręką swoją ścierasz łzy z oczu wiernych, pokaż się nam Ojcem wszelakiej pociechy ${ }^{7}$.

Centralnym motywem mowy kaznodzieja uczynił porównanie Barbary do świecy rozpalonej Bożą miłością, świecącej cnotami chrześcijańskimi. Ten wyrazisty obraz pobożnej niewiasty powraca w różnych kontekstach. Autor oświetla go za każdym razem innymi figurami z Pisma Świętego, aby stworzyć uniwersalny model świętości i przedstawić zgromadzonym wiernym wzór do naśladowania. Elementy panegiryczne, charakterystyczne dla pochwały zmarłego (np. przedstawienie rodu, wybitnych osiągnięć i dokonań), przeplatają się tu nieustannie z rozważaniami o nieubłaganej śmierci, konieczności wcześniejszego przygotowania się do niej, marności doczesnego życia i wiekuistej radości zbawionych. Postać bohaterki kazania odbija się w zwierciadle biblijnych figur; łączy ona w sobie zapobiegliwość Marty z pobożnością Marii (nazywanej konsekwentnie Magdaleną). Pod względem męstwa dorównuje Judycie, pogromczyni Holofernesa. Wraz z pannami roztropnymi zaopatrzyła swą lampę w oliwę (dobre uczynki). Zachowując przykazania i pełniąc dzieła miłosierdzia (opieka na ubogimi, sierotami i chorymi), naśladowała pokorę „służebnicy Pańskiej”. Pojawiają się także inne, dobrze utrwalone w tradycji literackiej obrazy: „mądrej” salamandry odpornej na płomienie codziennych trosk i zajęć, gołębicy Noego niosącej oliwę wewnętrznego pokoju, cudownego Feniksa spalającego się „w sprawiedliwości Pańskiej” i odradzającego się w potomstwie czy łabędzia wydającego przed śmiercią "głos przyjemny”.

Dubowicz podkreśla głęboką pobożność Barbary, stałość w prawdziwej wierze, odporność na nowinki religijne, wyjątkową gorliwość w modlitwie:

O to [o zgodność życia z wolą Bożą - W.R.] gorąco w codziennej, ręką własną swoją spisanej, a snadź i złożonej od siebie modlitwie, przykładem patronki wielkiej swojej, panienki i męczenniczki, Barbary świętej, do naświętszej i ożywiającej Trójce, upadając, temi słowy prosiła: „Panie Boże w Trójcy jedyny, zachowaj mię od wszytkiego złego, co by się woli Twojej świętej przeciwiło, a duszy mojej ku potępieniu miało być. Święty, święty, święty Panie Boże Zastępów, zachowaj i zastąp mię miłosierdziem Twoim nieogarnionym”. O, jasne i gorące miłości Bożej promienie głęboko do wnętrzności serca przenikające! O, dziwny kamieniu pirites [pirycie - W.R.] ogień z samego nieba do siebie powabiający! Z tej miłości Bożej pochodziło w niej ustawiczne, a nie tęskliwe z Panem Bogiem obcowanie przez modlitwy nabożne, psalmów pokutnych w duchu uniżonym odprawowanie, mawianie różańca i koronek, pasyjej i inszych modlitew, którymi się przykładem króla onego świętego z Panem i Stworzycielem swoim umawiała i praktykowała ${ }^{8}$.

$7 \quad$ J. Dubowicz, Kazanie na pogrzebie Jaśnie Wielmożnej Paniej, Jej M[ości] Paniej Barbary Naruszewiczówny, Januszowej Skuminowej Tyszkiewiczowej, wojewodzinej trockiej, jurborskiej, nowowolskiej etc. starościnej. Miane w cerkwi wileńskiej Trójce Przenaświętszej 2 dnia września roku P[ańskiego] 1627, [Vilnius 1627], k. A4v.-Br.

$8 \quad$ Ibidem, k. B4r.-B4v. 
Zmarła wielokrotnie przemawia w kazaniu słowami kaznodziei: zanosi gorące modlitwy do Boga, troszczy się o uposażenie kościoła św. Trójcy, wreszcie udziela na łożu śmierci błogosławieństwa córce i prosi małżonka, aby pamiętał o niej w swoich modlitwach. Ostatnie chwile życia Barbary stały się przedmiotem dłuższej, bardziej szczegółowej narracji. Kaznodzieja gromadzi niejako słuchaczy (czytelników) przy łożu umierającej, ukazując im przykład dobrej śmierci. Skrupulatnie relacjonuje jej pełne pokory i uniżenia modlitwy, napomnienia skierowane do męża i córki, pożegnanie ze służbą, ostatnie słowa. Zachęcając wiernych do „słodkiego” płaczu nad zmarłą, Dubowicz pozostaje przez cały czas wierny ustanowionej na początku kazania swoistej „ekonomii” oracji pogrzebowej: przemiany potoku łez w wezbrany strumień wymowy9.

Kiedy odbywały się uroczystości pogrzebowe w Wilnie, Sarbiewski przebywał w Połocku, gdzie w latach 1626-1627 prowadził wykłady z poetyki i retoryki w kolegium jezuickim założonym przez Stefana Batorego w 1580 roku. Wzmianka o towarzyszącym Barbarze małym wnuku pozwala określić w przybliżeniu czas powstania utworu. W połowie 1628 roku przyszedł na świat pierworodny syn Katarzyny Eugenii i księcia Janusza Wiśniowieckiego, który zmarł wkrótce po narodzinach. Małżeństwo doczekało się jeszcze dwóch synów (Dymitra Jerzego i Konstantego Krzysztofa) oraz dwóch córek (Anny i Barbary Katarzyny). Sarbiewski przebywał w Wilnie od 1628 roku. Początkowo wykładał poetykę i retorykę w Akademii Wileńskiej, później także filozofię scholastyczną. Można zatem przypuszczać, że pieśń adresowana do Janusza Tyszkiewicza, mimo podtytułu sugerującego okoliczności pogrzebowe („ostatnia posługa” oddana żonie), powstała najwcześniej w połowie 1628 roku, być może w pierwszą rocznicę śmierci albo pogrzebu Barbary i w związku z nowym nieszczęściem, jakie dotknęło rodzinę Tyszkiewiczów ${ }^{\mathbf{1 0}}$.

9 Do kazania (ibidem, k. E3r.-E4v.) dołączono również epitafium ułożone przez Janusza Tyszkiewicza, stanowiące główne źródło wiedzy na temat życia Barbary: „Barbara Naruszevicia / Castellani Smolenscensis f[ilia] / Palatina Trocensis etc. / Probitate morum / Familiae splendore / Dignitatis praerogativa / Clarissima / Verum integritate vitae, pietate in / Deum, dilectione in proxi- / mum, beneficentia in egenos, / amore et observantia erga / maritum, plusquam materno / in prolem affectu, rei famili- / aris cura, / quam longissime / clarior, / pudica, benigna, humilis, de- / vota, frugalis, sedula, sobria. / Speculum / exemplarque probitatis, / viva gaudium, mortua mari- / ti gemitus et luctu nunquam / finiendo / dolor / hic quiescit. / Quam animi dotibus concordia coniugali, / fortunae bonis, filia decora eiusdemque cum / Ill[ustrissimo] Ioan[ne] Korybuto duce / Wiszniewiecio, Capitaneo / Krzemienecen[si] instantibus nuptiis. / Fortunatam dixisses, / ni ea omnia / (ne quid humani non flu- / xum caducumque existimes) / importuna / mors / inopinanti ante tempus rapu- / isset. Cumque bene vixerit, / mortua beate / piissimeque defuncta / Dzitwae, / die 18. Iulii / Anno Salutis humanae / M.DC.XXVII. / aetatis suae 47, / coniugii 32. / Maestissimus maritus, / Ioan[nes] Skumin Tyszkiewicz, / Palatinus Trocen[sis], Bra- / slavien[sis], Iurborcen[sis], Novo- / volen[sis] etc. Capitaneus, / suae dulcissimae charissimaeque / coniugi, / nihil unquam de ea nisi mor- / tem questus, / marmor hoc / immortalium causa la- / crimarum / p[osuit]. Por. S. Starowolski, Monumenta Sarmatarum viam universae carnis ingressorum, Kraków: Vidua et haeredes Francisci Caesarii, 1655, s. 760-761; polskie tłumaczenie inskrypcji: E. Tyszkiewicz, Groby rodziny Tyszkiewiczów, Warszawa 1873, s. 30-31. Po raz pierwszy ukazała się w zbiorze: M.C. Sarbievius, Lyricorum libri quattuor, epodon liber unus alterque epigrammatum, Antwerpen: Officina Plantiniana Balthasaris Moreti, 1632, k. Bbv. - Bb2r. 
Chociaż poeta wiernie zachowuje strukturę retoryczną epicedium (opłakiwanie, pochwała zmarłego, pocieszenie), nieco inaczej rozkłada akcenty, wysuwając wyraźnie na pierwszy plan rozbudowaną konsolację. Wiąże się to z ograniczeniem komploracji i laudacji niemal do kilku słów. Lecz nawet i na tym polu Sarbiewski pozostaje daleki od powielania utartych formuł epicedialnych. Dokłada wielu starań, aby przejścia między poszczególnymi częściami pieśni były płynne i przejrzyste. Już w pierwszych wersach utworu wzywa Tyszkiewicza, „najdzielniejszego z możnych” (w. 3), do zaprzestania płaczu, gdyż nikomu Bóg ani Los nie obiecał na ziemi życia bez kresu. Zachęta do opłakiwania zmarłej ustępuje miejsca wezwaniu do powstrzymania łez, a użyta przez poetę argumentacja odwołuje się do dobrze znanej wszystkim prawdy o skończoności ludzkiego istnienia. Nieoczekiwanie przechodzi on jednak do krótkiej pochwały zmarłej. Nadaje tej laudacji postać wyliczenia cnót Barbary z umiarkowaniem, skromnością, gorliwością, zapobiegliwością i przezornością na czele. Uwagę czytelnika zwraca metafora „twierdzy umysłu” (arx animi) niewzruszonej żadną nawałnicą, wywodząca się ze słownika filozofii stoickiej. Aby opracować na nowo stałe elementy strukturalne epicedium, Sarbiewski z dużą pomysłowością wykorzystał potencjał perswazyjny pytania retorycznego. Wyliczenie zalet Barbary wpisane w ramy tej figury pozwala mu przełamać, a następnie zakwestionować granicę między komploracją a laudacją. Poeta zdaje się pytać: kogo nie wzruszą cnoty zmarłej? Znajduje w ten sposób usprawiedliwienie żałoby Tyszkiewicza, podając niejako w wątpliwość swe napomnienia z początku pieśni. Pytanie retoryczne, służące przede wszystkim wyrażaniu albo wzbudzeniu uczuć, może mieć, jak się okazuje, również udział w amplifikacji.

Pochwałę Barbary cechuje duża ogólność (a nawet ogólnikowość) i schematyczność. Poeta poprzestaje na prostym wyliczeniu zalet tworzących ideał chrześcijańskiej małżonki (pobożność, skromność, wstydliwość); nie wzbogaca go wyrazistym obrazem poetyckim. Niektóre z tych zalet przywodzą na myśl cnoty wypisane w epitafium, choć zostały one starannie dopracowane językowo. Zupełnie inaczej potraktował Sarbiewski kwestię pochwały kobiety w pieśni sławiącej Annę Radziwiłłową, kasztelanową trocką, księżną na Nieświeżu (III 9). Utwór powstał prawdopodobnie w 1628 roku z okazji ślubu Albrychta Władysława Radziwiłła (1589-1636), kasztelana trockiego (od 1626), z Anną Zofią Zenowiczówną (zm. 1664), córką kasztelana połockiego, Mikołaja Bogusława Zenowicza ${ }^{11}$. Poeta uruchamia akcję panegiryczną spod znaku porównywania nieporównywalnego. Zastanawia się nad imieniem bogini, którym mógłby najpełniej uczcić bohaterkę pieśni, „Nimfę znad Dniepru” (Nympha Borysthenis). Ustępuje przed nią bowiem cały orszak bóstw z Wenus i Dianą na czele. Jej tymczasem przynoszą sławę „spokojne zajęcia Pallady” (tranquilla Palladis otia). Jako uczennica Ateny, ale najwyraźniej bez pychy i pragnienia współzawodnictwa

11 W edycji liryków i epigramatów Sarbiewskiego z 1630 roku (Lyricorum libri tres, epigrammatum liber unus, edita tertia auctior, Antwerpen: Johannes Cnobbar) utwór opatrzono następującym tytułem: Illustrissimae sponsae Annae Zenowiciae panegyris. Dwa lata później (Antwerpen 1632) został on zmieniony na: Panegyris Annae Radiviliae, Castellanae Trocensis, Ducissae Nesvisii. 
Arachne, „opowiada” ona złotą nicią o wojnach mężów (bella virum), snując kobiecą dłonią „męską”, epicką „narrację” o nieśmiertelnej chwale zdobytej w boju, albo okrywa purpurowymi kobiercami „nagie ołtarze” (nudas aras). Wyróżnia ją mądrość, zapobiegliwość i skromność. Panegiryczną pieśń wieńczy sentencjonalna formuła o niezwykłej wartości duchowego piękna: „gdy błyszczy prawdziwa cnota, wszystkie klejnoty kryją się w ciemnościach"12. Podobnie jak w przypadku Barbary Tyszkiewiczowej, portret Anny Radziwiłłowej ukazuje postać pobożnej, uczciwej małżonki i troskliwej gospodyni, rozkwitającej najpełniej w domowym zaciszu, w cieniu męża sławnego chociażby tylko dzięki pełnionym urzędom.

W pieśni adresowanej do Tyszkiewicza łącznikiem między krótką, schematyczną laudacją a częścią konsolacyjną, w pełni rozwiniętą i autonomiczną, jest poetycki katalog „pań mężnych”. Został on niemal w całości zapożyczony ${ }^{\mathbf{1 3}}$ z panegiryku Klaudiana dla Sereny, siostrzenicy cesarza Teodozjusza I, żony wodza wojskowego, Stylichona (Laus Serenae reginae uxoris Stiliconis). Sarbiewski wylicza kobiety z odległej, często zmitologizowanej przeszłości, które zasłynęły heroicznymi czynami. Przypomina Tanakwil, żonę Tarkwiniusza Starego, uosobienie cnót rzymskiej matrony troszczącej się o poddanych; Klaudię Kwintę, która chwyciła linę i przyciągnęła statek wiozący posąg Kybele do Rzymu; Alcestis, tesalską królową, która - mówiąc słowami Jana Kochanowskiego - „męża od śmierci zastąpiła”, i Klelię, która uciekając z etruskiej niewoli, przepłynęła Tyber. Wyliczenie słynnych kobiet, mających raczej niewiele wspólnego z Barbarą z Naruszewiczów, służy jednak nie tyle dopełnieniu wcześniejszej pochwały, ile raczej wprowadzeniu nowego wątku, kluczowego dla późniejszej konsolacji. Mowa o ocalającej mocy poezji, zapewniającej przedłużenie krótkiego życia dzielnych niewiast w pieśniach poetów. Ich twórczość, ożywiona pragnieniem uobecnienia i upamiętnienia zmarłych, może przynieść poetycką nieśmiertelność.

Nic więc dziwnego, że konsolację otwiera obraz Orfeuszowej lutni (Orphea testudo $)^{\mathbf{1 4}}$, najbardziej sugestywnie wyobrażający zwycięstwo pieśni nad nieczułym światem natury (drzewami, kamieniami, groźnymi zwierzętami) i mrocznym królestwem zmarłych. W mitycznej narracji o trackim wieszczu poezja może triumfować nawet nad nieubłaganą śmiercią, tworząc iluzję powrotu do „krainy żyjących”. Dlatego Orfeusz stał się mistrzem i przewodnikiem dla wszystkich poetów wyruszających w zaświaty. Chociaż większość z nich nie przekroczyła nigdy bram Podziemi, ich pieśni zawdzięczają wiele poszukiwaniom jego śladów, choćby tylko tekstowych.

12 Sarbievius 1634, Lyr. III 9, 35-36: „cum pura virtus fulsit, omnes / in tenebris latuere gazae”.

13 Wszystkie zapożyczenia tekstowe odnotowano w objaśnieniach do pieśni.

14 Postać Orfeusza pojawia się także w liście dedykacyjnym Jana Dubowicza do Janusza Tyszkiewicza z 1 grudnia 1627 roku: „[...] na takich łez otarcie nie z Orfeuszową albo Orionową melodią (gdyż in luctu musica importuna narratio [«jak muzyka w czas smutku, tak nauka w niewłaściwym czasie», Syr 22,6 - W.R.]) przychodzę interpellaturus [mając pocieszać - W.R.] W[aszą] M[ość] mego Mości Pana, ale Patrem misericordiarum et Deum totius consolationis [Ojca miłosierdzia i Boga wszelkiej pociechy - W.R.] na uciechę przynoszę, wzywam i proszę, pewien będąc, że nad to skuteczniejszej nikt przynieść nie może. On sam niech otrze łzy od oczu twoich”, J. Dubowicz, Kazanie na pogrzebie Jaśnie Wielmożnej Paniej, Jej M[ości] Paniej Barbary Naruszewiczówny..., k. A3r. 
Kiedy po raz drugi utracił on ukochaną Eurydykę, napełnił „żałosną pieśnią” ( $m i$ serabile carmen) brzegi Strymonu (Georg. IV, 507-515) ${ }^{\mathbf{1 5}}$. Samotny, niepocieszony, siedzący w blasku „mroźnych gwiazd” (sub gelidis astris), pogrążony w niewysłowionym żalu, został patronem twórczości epicedialnej przechowującej w sobie gorzką świadomość nieodwracalności straty. Eneasz podczas wędrówki po zaświatach widzi, jak ubrany w długą szatę „tracki kapłan” (Threicius sacerdos) sprawia cieniom przyjemność grą na lutni o siedmiu strunach (Aen. VI, 644-647).

W odzie adresowanej do Wergiliusza po śmierci Kwintyliusza Warusa, realizującej założenia retoryczne poezji żałobnej (cantus lugubris), Horacy (Carm. I 24, 13-18) kwestionuje sens współzawodnictwa z Orfeuszem, gdyż nawet najbardziej poruszająca pieśń nie może przywrócić życia „marnym cieniom” ${ }^{16}$. Epikurejska mądrość podpowiada, aby nie tracić czasu na niekończące się lamenty, a ciągłe przypominanie tej prostej prawdy stanowi rodzaj ćwiczenia z parezji (libertas dicendi), otwartości i szczerości, szczególnie istotnej w pielęgnowaniu prawdziwej przyjaźni ${ }^{17}$. Drogę do konsolacji otwiera tylko cierpliwość, wytrwałość (patientia) w znoszeniu tego, czego nie można (nefas) już zmienić, przywrócić do wcześniejszego stanu, naprawić (corrigere); to ostatnie słowo nabiera dodatkowego znaczenia, jeśli weźmiemy pod uwagę działalność Warusa jako surowego i rzetelnego krytyka literackiego ${ }^{\mathbf{1 8}}$. Nikt, nawet natchniony poeta, nie może skorygować „błędów” śmierci; poprawić można co najwyżej źle napisaną czy niedopracowaną pieśń żałobną. Naśladowcom trackiego wieszcza pozostaje zatem poezja pozbawiona mocy odwoływania wyroku śmierci, pogodzona z nieuniknionym cierpieniem, świadoma swoich ograniczeń. I w takiej, skrojonej na miarę ludzkich możliwości, formie musi ona wystarczyć.

Również Sarbiewski eksponuje bezcelowość naśladowania Orfeusza, ale czyni to zupełnie inaczej. Jego poruszająca „nieczułe cienie” (w. 25-26) lutnia na niewiele się przyda, gdyż niebiosa (Elysium) są otoczone spiżowymi murami, a potężne bramy pozostają głuche na prośby śmiertelników. Poeta zamyka je przed Orfeuszową pieśnią, aby otworzyć nowe możliwości konsolacji. Ustanawia przeszkodę, która zmusza go do intensywnych poszukiwań. Cały wysiłek inwencyjny wkłada w przezwyciężenie stworzonej przez siebie wcześniej komplikacji. Doświadczenie trackiego mistrza uczy pokory wobec oczekiwań i nadziei rozbudzonych przez poetów. O ile jednak

15 Por. Z. Kubiak, Szkoła stylu. Eseje o tradycji poezji europejskiej, Warszawa 1972, s. 21-22.

16 Por. A. Khan, Horace's Ode to Virgil on the Death of Quintilius: I.24, „Latomus” 26 (1967), s. 107-117; S. Thom, “That No Man Lives Forever”: Horace on the Death of Quintilius (1.24), „Akroterion” 41 (1996), no. 3-4, s. 114-123.

17 Por. Ph. Thibodeau, Can Vergil Cry? Epicureanism in Horace Odes 1.24, „The Classical Journal” 98 (2003), no. 3, s. 243-256.

18 Por. M.C.J. Putnam, The Language of Horace Odes 1.24, „The Classical Journal” 88 (1993), no. 2, s. 134: „[... Horacy przyjmuje rolę pedagoga wydającego polecenia Muzie jak nauczyciel lub mistrz filozofii swemu uczniowi. Sam staje się reinkarnacją Warusa, prawdziwym i szczerym krytykiem, przywracającym go do życia w taki sposób, w jaki Wergiliusz nie może tego uczynić w swojej bardzo poważnej żałobie. Za pomocą językowych sztuczek Horacy osiąga coś, co Orfeusz-Wergiliusz musiał w jałowej, nieuzasadnionej gorliwości uznać z konieczności za niemożliwe”. 
moc sprawcza poezji w przywracaniu zmarłych do życia jest mocno ograniczona, o tyle jej zdolność do wewnętrznej renowacji obejmującej rzeczy i słowa wydaje się niczym nieskrępowana. Sarbiewski jako nowy Orfeusz wzbogaca jego poetyckie mistrzostwo o przebiegłość Odyseusza. U zamkniętych bram niebios szuka sposobu, aby przynajmniej przez chwilę zobaczyć ich mieszkańców. Odkrywa niewielkie szczeliny w bramie (synekdocha in limine) odsłaniające tajemnice (w. 30-31).

Metafora szczelin nieba wiąże się w poezji Sarbiewskiego z gwiazdami. W jednej z czterech pieśni maryjnych składających się na dedykowany Januszowi Skuminowi Tyszkiewiczowi cykl epod ${ }^{\mathbf{1 9}}$, powstałych z okazji uroczystej procesji dziękczynnej (wiktoria chocimska), która odbyła się wiosną 1622 roku do sanktuarium Matki Bożej w Trokach ${ }^{\mathbf{2 0}}$, poeta łączy Maryję z obrazem rozgwieżdżonego nieboskłonu: "gdy milczący zastęp gwiazd rozciąga się na pogodnym niebie, a przybytek błyszczących niebios jaśnieje dzięki wszystkim szczelinom światła"21. Gwiazdy okazują się zatem świetlistymi szczelinami niebiańskiego gmachu. W lirycznej konsolacji dla Tyszkiewicza szpary w bramach nieba pozwalają zobaczyć jak przez dziurkę od klucza rzeczy ukryte przed śmiertelnikami. Użyta przez poetę metafora może mieć również znaczenie tekstualne. Szczeliną, przestrzenią pozostawioną między figurą (obrazem poetyckim) a figurą (innym obrazem), umożliwiającą wgląd w zaświaty jest bowiem pieśń przynosząca pocieszenie. Zapis widzenia poety pozwala jej adresatowi, a następnie każdemu czytelnikowi, mieć swój udział w podglądaniu niebian.

Poetycka wizja stanowi istotę konsolacji. Zgodnie z poetyką niezwykłości Sarbiewski bardzo wyraźnie sygnalizuje przejście do części wizyjnej utworu: „albo widziałem, albo zdawało mi się, że widziałem” (w. 34). Obraz zaświatów ${ }^{22}$ tylko na krótką chwilę wyłania się ze złocistej światłości. Każdy element tego przedstawienia lśni cudowną jasnością. Spośród różnorodnych barw retorycznych (colores rhetorici)

19 Te cztery pieśni ukazały się zdaniem Ippolita Marracciego (1604-1675) w Antwerpii już w 1624 roku jako Quattuor Leucas Virginis Matris seu publicam ac solemnem ad aedem Divi Virginis Matris Trocensem processionem odis quattuor, Antwerpen: typis Monti, 1624; por. H. Marracci, Bibliotheca Mariana alphabetico ordine digesta, t. II, Roma: Franciscus Caballus, 1648, s. 108. Dedykację dla Tyszkiewicza dodano po 1626 roku (objęcie urzędu wojewody trockiego). Marracci zamieścił również krótką informację o Sarbiewskim: „Matthias Casimirus Sarbievius, Societate Iesu, natione Polonus, seu Lithuanus, gente Mazovita, vir omni scientiarum genere excellens, serenissimi Poloniae regis Vladislai IV. concionator et poeta Urbano VIII. Pontifici Maximo probatus". Wśród dzieł maryjnych poety wymienił również kazania „pro festis Deiparae”.

20 Por. interpretację wybranych motywów z tych pieśni: E. Buszewicz, Sarmacki Horacy i jego liryka..., s. $372-379$.

21 Sarbievius 1634, Ep. 10, 81-84: „quale, dum puro taciturna caelo / siderum se fert acies, per omnes / ignium rimas nitidi renident / atria caeli”. Podobny obraz (acies astrorum), wywiedziony na zasadzie paronomazji z biblijnej frazy „zastępy w szyku” (acies castrorum, Pnp 6,10), pojawia się w pieśni IV 22, 9-12: „Cinge maternis Puerum lacertis, / Sol eris vel quae vigil explicatis / siderum turmis acies tonantem / circumit aulam".

22 Por. M. Łukaszewicz-Chantry, Raj chrześcijański na Polach Elizejskich. Analiza dwóch pieśni Macieja Kazimierza Sarbiewskiego, „Pamiętnik Literacki” 91 (2000), z. 1, s. 179-180, 184-186; eadem, Trzy nieba..., s. 82-84, 121-122. 
poeta najczęściej sięga po złoto. Chociaż tworzy tylko szkic niebiańskiego Elizjum, przywiązuje dużą wagę do detalu. Wyzłaca nawet rozciągające się łąki i liście okrywające drzewa. Fiołki błyszczą tu niczym klejnoty. W złocistym blasku niegasnących gwiazd trudno rozróżnić zarysy postaci i rzeczy. Jeśli uznać ten skreślony kilkoma pociągnięciami pióra świetlisty obraz za ekfrazę zaświatów, to można powiedzieć, że wyłania się on i szybko znika w niebiańskiej jasności, pozostawiając olśnionego - a może nawet oślepionego tym niezwykłym światłem - czytelnika z poczuciem niedosytu. Poeta nieprzypadkowo sięga po toposy niewyrażalności: farby Apellesa (w. 39) metonimicznie oznaczającej doskonałą pod względem reprezentacji sztukę malarską i przejrzystego, trójkątnego kryształu łudzącego zwodniczym odbiciem (w. 40); ani „apellejska barwa”, ani żadne szkło o regularnej strukturze nie odda piękna tego obrazu.

Wizję zaświatów w poezji Sarbiewskiego kształtują zarówno wyobrażenia antyczne (Pola Elizejskie, Wyspy Szczęśliwe, rzeczywistość złotego wieku), jak i chrześcijańskie (raj, królestwo Boże, niebiańskie Jeruzalem). Przenikają się one do tego stopnia, że czasami trudno powiedzieć, gdzie przebiega między nimi granica. Bardzo duże nasycenie wizji niebios jasnością w tej pieśni konsolacyjnej pozwala przypuszczać, że źródłem tego obrazowania było apokaliptyczne widzenie Miasta Światłości, w którym „już nocy nie będzie. A nie potrzeba im [mieszkańcom Miasta - W.R.] światła lampy ani światła słońca” (Ap 22,5). Źródłem światła w niebieskiej ojczyźnie są „nowe” gwiazdy (virides stellae) i „błyszczące światła” (corusca sidera) niebios oświetlające złociste łąki (w. 43-44). Wielki, wysoki mur, solidne i potężne fundamenty zbudowane $\mathrm{z}$ drogocennych kamieni, okazałe bramy odsyłają wprost do biblijnego opisu (Ap 21,10-27). Jak powiada św. Jan, „Miasto - to szczere złoto do szkła czystego podobne” (Ap 21,18). Jest ono przestrzenią otwartą, harmonijnie uporządkowaną, pełną niewysłowionego uroku. Współgra z tą wizją opis zielonych łąk przeznaczonych dla szczęśliwych cieni, które odwiedza Eneasz podczas wędrówki po zaświatach w towarzystwie Sybilli $^{23}$. Te miejsca powszechnej radości, śpiewu i tańców spowija „purpurowe światło”. Mają one bowiem, jak przypomina Wergiliusz, „swoje słońce i swoje gwiazdy" (Aen. VI, 640-641).

Obraz niebiańskiego miasta (urbs caelestis) Sarbiewski przywołał w późniejszym kazaniu okolicznościowym, które wygłosił 14 sierpnia 1636 roku w obecności Władysława IV i dworu królewskiego podczas uroczystej procesji z okazji przeniesienia (translacji) relikwii św. Kazimierza do nowej kaplicy w katedrze wileńskiej ${ }^{\mathbf{2 4}}$ :

${ }^{23}$ Por. J. Sokolski, Staropolskie zaświaty. Obraz piekła, czyśćca i nieba w renesansowej i barokowej literaturze polskiej wobec tradycji średniowiecznej, Wrocław 1994, s. 115-118.

24 Por. relację z tego wydarzenia: A.S. Radziwiłł, Pamiętnik o dziejach w Polsce, t. 1: 1632-1636, przeł. i oprac. A. Przyboś, R. Żelewski, Warszawa 1980, s. 555-556. Sarbiewski, „ozdobiony płaszczem doktorskim" (ibidem, s. 555), wygłosił z ambony kazanie przed wyruszeniem uroczystej procesji. 
Non haec eo dico, auditores, neque is est sensus orationis meae, quasi haec sint praemia, hi honores, qui animo, qui corpori Casimiri praecipue debeantur; alia est enim gloria, alia merces, quae beatissimae illi menti posteaquam e corpore excessit merito tribuitur, alii triumphi hoc castissimum corpus in caelo manent, quorum hodierna haec pompa umbra quaedam est et fugitiva ac brevis imago. Erit enim tempus, erit, auditores, cum hoc idem corpus, non argenteo loculo reconditum, sed sincera atque innubila immortalitatis luce perfusum, non per pulverulentas urbis alicuius plateas, sed per vicos caelestis Hierusalem, gemmis atque auro collucentes, non sub arcubus temporariis, sed sub smaragdinis sapphirinisque porticibus, non inter breves ac cito morituros symphoniae sonos, sed inter immortales choros, neque transitorio, sed perenni triumpho, neque sub aliquod caducum mausoleum, sed in aeternum beatorum Capitolium devehetur ${ }^{25}$.

[Nie o tym mówię, słuchacze, i nie takie jest znaczenie mojej mowy, gdyż inne są te nagrody, te zaszczyty, które należą się szczególnie duszy i ciału Kazimierza; inna jest bowiem chwała, inna zapłata, na którą zasługuje ta błogosławiona dusza, gdy opuściła już ciało; inne uroczystości czekają na to najczystsze ciało w niebie; to dzisiejsze święto jest ich jakimś cieniem, przemijającym i znikomym odbiciem. Nadejdzie bowiem czas, słuchacze, nadejdzie, gdy to ciało będzie prowadzone, nie ukryte w srebrnej trumnie, ale oblane prawdziwym i niezamglonym światłem nieśmiertelności; nie przez pokryte kurzem ulice jakiegoś miasta, ale przez drogi niebiańskiego Jeruzalem, błyszczące klejnotami i złotem; nie przez tymczasowe bramy, ale przez szmaragdowe i szafirowe portyki; nie wśród krótkich i szybko zamierających dźwięków muzyki, ale wśród nieśmiertelnych chórów; nie podczas przemijającego pochodu, ale wiekuistego święta i nie do jakiegoś nietrwałego grobowca, ale do wiecznego przybytku błogosławionych].

Królewski kaznodzieja posłużył się alegorezą dobrze znaną z tradycji patrystycznej, często stosowaną w hermeneutyce biblijnej. Eksplikacja figur zakłada przywołanie innych tropów i schematów retorycznych. Ta strategia interpretacyjna pozwoliła Sarbiewskiemu wpisać aktualne wydarzenia w pewien uniwersalny, uwolniony od historycznego dookreślenia porządek znaczeń. Z tego powodu uroczysta procesja z ciałem św. Kazimierza stała się niedoskonałym obrazem czy odbiciem orszaku błogosławionych w niebie. Mówca ujawnia słuchaczom (czytelnikom) ukryty sens zdarzeń, podkreślając napięcie semantyczne między szybko przemijającą doczesnością a stałą i niezmienną wiecznością. Mocą poetyckiego słowa przemienia pokryte pyłem ulice Wilna w lśniące złotem drogi niebiańskiego Jeruzalem.

W pieśni konsolacyjnej Sarbiewski wyraźnie określił ramy wizji niebiańskiej krainy. Początkowa formuła poświadczająca poetyckie widzenie przywodzi na myśl

25 M.C. Sarbiewski, Oratio panegyrica habita in praesentia Serenissimi ac Invictissimi Vladislai IV, Poloniae et Sueciae regis in solenni corporis divi Casimiri translatione priusquam publica processione per urbis Vilnae plateas in regium cathedralis templi sacelium deferretur. Anno 1636 14. Augusti, Vilnius: Typis Academicis Societatis Iesu, 1636, k. A4r.-A4v. Por. J. Zaborowska-Musiał, Obraz miasta ziemskiego i niebiańskiego $w$ Oratio in sollenni corporis divi Casimiri translatione habita Macieja Kazimierza Sarbiewskiego, „Meander” 70 (2015), s. 113-129. 
spotkanie Eneasza z milczącym wymownie cieniem Dydony na Polach Rozpaczy (Lugentes Campi); bohater przypomina wówczas kogoś, kto „ujrzał albo zdawało mu się, że ujrzał księżyc wschodzący wśród chmur” (Aen. VI, 453-454). Przez szczeliny poeta może dostrzec to, czego ludzkie „oko nie widziało” (1 Kor 2,9), a co być może objawiono pewnemu człowiekowi (zapewne samemu św. Pawłowi) porwanemu „aż do trzeciego nieba” (2 Kor 12,2). Kres wizji kładzie jednak szybko mgła o niezwykłej jasności (w. 49-50). Błyszczący złotem i światłem gwiazd obraz zaświatów znika w rozbłysku. Wszystko pogrąża się w cudownej, nieziemskiej świetlistości. Wcześniej, stojąc u bram niebios, poeta wierzył w możliwość zobaczenia tajemnic ukrytych przed śmiertelnikami, teraz podkreśla słabość ludzkiego oka, oślepionego blaskiem niebiańskiej ojczyzny.

Poeta widział jednak wystarczająco dużo, aby stworzyć obrazową konsolację. Ujrzał pełną życia Barbarę „o różanym obliczu” (w. 46), która wędrowała w towarzystwie „małego wnuka” (w. 45) przez złote pola i splatała wieńce z kwiatów dla siebie i chłopca. Autor sięga znów po frazeologię Wergiliusza, choć znacząco zmienia kontekst. Słowa odnoszące się pierwotnie do Salmoneusa, władcy Elidy domagającego się boskiej czci i surowo ukaranego przez Jowisza, wykorzystuje w opisie radości Barbary (Aen. VI, 589) ${ }^{\mathbf{2 6}}$. Ta krótka relacja z zaświatów stanowi istotę pocieszenia. Podglądanie niebian służy nie tyle wstępnemu rozpoznaniu topografii nowego Jeruzalem, ile raczej zaświadczeniu, że zmarli wciąż żyją i mają się jeszcze lepiej niż tu na ziemi. Poeta uobecnia Barbarę w scenerii chrześcijańskiego nieba. Stawia ją przed oczami czytelników pieśni dokładnie w takiej postaci, w jakiej ujrzał ją podczas tej przechadzki. Jako naoczny świadek jej nowej, wiecznej szczęśliwości potwierdza, że dopiero teraz cieszy się ona pełnią istnienia.

Zamykający pieśń dwuwiersz łączy w sobie napomnienie skierowane bezpośrednio do adresata $z$ sentencjonalnie wyrażoną mądrością o wiekuistym życiu niebian. Imperatywna formuła „nie chciej więcej” (w. 51) ustanawia granice dla poszukiwań pocieszenia, wzywa do pogodzenia się z losem. Czy adresatem tego wezwania jest tylko Tyszkiewicz? Czy nie jest nim również autor (a także, w dalszej perspektywie, czytelnik), wkraczający w przestrzeń niedostępną dla nawet najbardziej wtajemniczonych wieszczów? Poeta odważył się podglądać mieszkańców niebios, ale także podzielić się swoim widzeniem z innymi czytelnikami. Okiem natchnionego poety zobaczył rzeczy ukryte przed śmiertelnikami. Jego mediacja między światem a zaświatami musi z konieczności wystarczyć. Ostatnie słowa utworu wyrażają tę prawdę za pomocą antytezy, uwydatniającej przemianę ulotnej doczesności (caduca) w niezmienną wieczność (aeternis) ${ }^{\mathbf{2 7}}$.

26 Na tę zależność tekstową zwróciła wcześniej uwagę Maria Łukaszewicz-Chantry, Raj chrześcijański na Polach Elizejskich..., s. 180.

27 Por. zakończenie ody w przekładzie Adama Naruszewicza: „Więcej dla blasku nieobjętej łuny / Wzrok nie potrafił doścignąć człowieczy. / Ni ty chciej więcej: trzykroć ten fortunny, / Kto za znikome wiecznych dostał rzeczy!", Oda Sarbiewskiego do Janusza Skumina..., s. 405. 
Ciekawym kontekstem dla omawianej pieśni może być swoista „trylogia epicedialna” z księgi trzeciej liryków Sarbiewskiego (III 24, III 25, III 26). Trzy następujące po sobie ody napisane strofą alcejską realizują w podobny sposób założenia poezji żałobnej. W każdej z nich na pierwszy plan wysuwa się konsolacja. W pieśni adresowanej do Jana Rudominy Dusiackiego (1581-1646), rotmistrza husarskiego, kasztelana nowogródzkiego (III 24), poeta uwiecznił bohaterską śmierć jego brata Jerzego (1591-1621) w bitwie pod Chocimiem ${ }^{28}$. Epicki temat podsunął mu zapewne rozbudowane homeryckie porównanie; pierwszy człon tego obrazowego zestawienia tworzy aż pięć strof ukazujących gwałtowne uderzenie błyskawicy, która uciekła $\mathrm{z}$ „wstrętnego więzienia szemrzących chmur” (w. 4-5). Z takim samym impetem śmierć uderza w walczącego Rudominę. Kiedy rotmistrz upada pod mieczem nieprzyjaciela na polu chwały, natychmiast na wpół żywego podnoszą go Zaszczyt (Decus) i Cnota (Virtus), a Sława (Fama) wynosi aż gwiazd, głosząc całemu światu: „żyje, mój Rudomina wśród gwiazd żyje!” (w. 51-52) ${ }^{29}$. W pieśni upamiętniającej śmierć Jana Rudominy Dusiackiego ${ }^{30}$, wojskiego brasławskiego, adresowanej do jego syna, wspominanego już Jana (III 25), Sarbiewski powtarza motyw lotu do niebiańskiej ojczyzny, dostosowując go do potrzeb nowej akcji panegirycznej. Swobodnie snuje liryczną opowieść o znikomości, ulotności doczesnej sławy, o ziemskich troskach obciążających skrzydła ludzkiego umysłu, wreszcie o śmierci sprawiedliwego pozwalającej mu wzlecieć w przestworza. Zmarły unosi się coraz wyżej, aby ostatecznie zająć miejsce w przybytku błogosławionych. Niczym stoicki mędrzec może teraz z obłoków spoglądać niewzruszonym okiem na śmieszny spektakl Fortuny: błyszczące ostrza wzniesionych mieczy czy upadające wielkie miasta. W trzeciej pieśni, poświęconej Ernestowi Wejherowi, synowi wojewody chełmińskiego (III 26), „przedwcześnie zmarłemu” (zmarł jako uczeń kolegium jezuickiego w Braniewie w 1617 roku), poeta, parafrazując słynne pytanie św. Pawła ${ }^{31}$, zwraca się do śmierci: „czemu, o Śmierci, jako zwyciężczyni nadymasz nienasycone serce podmuchem pychy, sadząc zwycięskie cyprysy i pozbawione igieł cisy?"32. Jak można się łatwo domyślić, jej triumf okazuje się złudny. Poeta rozwiewa tę iluzję dydaktycznym wykładem o nieprzemijających wartościach duchowych. Cnota młodzieńca (virtus

28 Jan Rudomina dowodził oddziałem stu husarzy (chorągwią) wchodzącym w skład pułku Mikołaja Zienowicza, kasztelana połockiego. Urządził pogrzeb brata w kościele bernardynów w Wilnie, a ośmiu poległych towarzyszy pochował w nowogródzkiej farze pw. Przemienienia Pańskiego, por. K. Kolendo-Korczak, Nagrobek Jerzego Rudominy i ośmiu towarzyszy poległych w bitwie pod Chocimiem $w 1621$ roku, „Przegląd Wschodni” (2001), nr 27-29, s. 875-886.

Sarbievius 1634, Lyr. III 24, 51-52: „At Fama late tergemino tubae / longaeva cornu saecula personat: / Io, triumphe! Vivit astris / ille meus Rudomina, vivit!”.

30 Jan Rudomina Dusiacki (ok. 1543-1621), herbu Trąby, najstarszy syn Macieja Rudominy, wojski brasławski. Zmarł 21 lipca 1621 roku i został pochowany wspólnie z synem, Jerzym, poległym pod Chocimiem, w bernardyńskim kościele św. Franciszka w Wilnie 21 lutego 1622 roku.

31 Por. 1 Kor 15,54-55: „Gdzież jest, o śmierci, twoje zwycięstwo? Gdzież jest, o śmierci, twój oścień?”.

32 Sarbievius 1634, Lyr. III 26, 29-32: „Quid, Mors, superbo pectora turbine / insana victrix surrigis, inserens / terris triumphales cupressos / et mutilam sine fronde taxum?”. 
Veiherana) umieszcza go bowiem wśród gwiazd, aby stał się wzorem dobrego przeżywania krótkotrwałej młodości.

W trzech przywołanych pieśniach Sarbiewski na różne sposoby opracował motyw lotu ku gwiaździstym niebiosom. Wariacja tematyczna stanowi w tym przypadku niezawodną strategię inwencyjną, pozwalającą na wprowadzenie niewielkich, lecz znaczących zmian do pierwotnego projektu. Jest to wariacja z powtórzeniem. Za każdym razem poeta dostosował opowieść o wznoszeniu się w przestworza do życia i osiągnięć zmarłego, okoliczności jego śmierci, oczekiwań adresata (czytelników), intencji panegirycznej i dydaktycznego przesłania. I chociaż zmieniają się niektóre elementy przedstawienia, zasadniczy koncept konsolacyjny pozostaje taki sam. Głęboka pobożność Jana Rudominy, śmierć na polu chwały jego syna Jerzego i cnota Ernesta Wejhera zapewniają im udział w wiekuistej radości niebiańskiej krainy. Poeta rozpisuje niejako motyw pośmiertnego lotu na trzy liryczne narracje, zwieńczone nauką o nagrodzie za dobre, cnotliwe życie oddane służbie Bogu i ojczyźnie.

Pieśń adresowana do Tyszkiewicza stanowi w kontekście „trylogii epicedialnej” z trzeciej księgi liryków interesujące świadectwo ewolucji poetyki Sarbiewskiego. Jej zasadniczym rysem pozostaje autonomizacja fikcji lirycznej. Inwencyjne poszukiwania poety zmierzają nie tyle do renowacji coraz bardziej skonwencjonalizowanego motywu, ile raczej do wynalezienia nowej, najlepiej nieoczywistej, zaskakującej opowieści. Lot poety do bram niebios został w tej odzie zupełnie zmarginalizowany. Uwagę czytelnika przykuwa pomysł z podglądaniem niebian przez szpary w bramie niebiańskiego miasta, widzenie zaświatów tonących w jasności, radosna postać Barbary wędrującej z wnukiem złotymi łąkami. Z procesem zdobywania coraz większego znaczenia przez narrację liryczną wiąże się rewaloryzacja statusu natchnionego wieszcza. Tylko dzięki jego poetyckiej aktywności możliwe staje się uchylenie tajemnicy skrytej przed śmiertelnym okiem.

Wspomnianą wcześniej odę Horacego otwiera słynne pytanie: czy istnieje jakiś umiar, jakaś granica w opłakiwaniu ukochanej osoby? (Carm. I 24, 1-2). Musi się z nim, choćby tylko retorycznie, zmierzyć każda konsolacja, odwołująca się najczęściej do sprawdzonych, utrwalonych w tradycji formuł. Pozostaje ona jednak zawsze próbą inwencji poetyckiej, gruntowną renowacją utartych motywów, figur, obrazów. Pieśń mająca przynieść ukojenie Tyszkiewiczowi stanowi przede wszystkim opowieść o pocieszeniu, jakie daje wiarygodna fikcja liryczna. I jeśli tracimy nagle z oczu bohaterkę konsolacji, wciąż pamiętamy o przenikliwym spojrzeniu poety, szczelinach niebios oświetlających go złocistym światłem, jego błyskotliwym umyśle snującym sugestywną narrację, wreszcie sprawnym piórze utrwalającym ulotną, poetycką wizję i zapewniającym jej niezwykłą siłę wyrazu. 


\section{Maciej Kazimierz Sarbiewski}

\section{30 Ad Ianussium Skuminum Tyszkiewicium, palatinum trocensem}

Cum Barbarae Naruszewiciae, coniugi carissimae, iusta persolveret

Si tibi pollicitum Numen, si fata fuissent

aeternos fore coniugis annos,

iure per assiduos, procerum fortissime, fletus

ereptam quererere, Ianussi.

Quem pietas, quem non moveat non tristibus umquam

arx animi concussa procellis

et pudor, et proni niveo de pectore sensus,

et regina modestia morum,

aut bona sedulitas, aut non incauta futuri

praesagae solertia mentis?

Provida sed longum magnis virtutibus aevum

non audent promittere fata;

nec possunt, si quae maturavere, profanis astra diu committere terris.

Nunc adeo parces longis onerare querelis

depositum repetentia magnum,

ingentes animi gazas et robur et aureo

incoctum bene pectus honesto.

Sic Tanaquil, sic quae cunctantem Claudia rexit

virginea cervice Cybeben,

quaeque maritali successit Thessala fato

et Latiis vaga Cloelia ripis,

ante diem raptae vivunt post funera vatum

perpetuos in carmine fastos.

Illa quidem non, si surdos ad carmina manes

Orphea testudine vincam,

eductas adamante fores et ahenea rumpat

Elysii pomoeria muri

reddaturque tibi. Stat nulli ianua voto,

nullis exorata poetis.

Sunt tamen exiles insigni in limine rimae,

qua possint arcana videri. 
Hac ego, si nullos fallunt insomnia manes, aut vidi, aut vidisse putavi

errantem campo in magno, quem gemmea circum 35 perspicuis stant moenia portis.

Auro prata virent, arbor crinitur in aurum, crispantur violaria gemmis, quae nec Apelleus liquor, nec pulchra trigoni assimulent mendacia vitri.

Centum ibi formosis in vallibus heroinae aeternum paeana frequentant.

Stant virides campo stellae madidisque corusca connivent sibi sidera flammis.

Illa inter medias parvo comitata nepote et roseo vivacior ore

ibat ovans grandemque sibi, grandemque nepoti nectebat de flore coronam.

Caetera me vetuit magni caligo sereni mortali percurrere visu.

$\mathrm{Nec}$ tu plura velis. Satis est, cui fata dederunt aeternis mutasse caduca. 


\section{30 Do Janusza Skumina Tyszkiewicza, wojewody trockiego}

Gdy oddawał ostatnia posługę Barbarze z Naruszewiczów, najdroższej żonie

Gdyby Bóg ci obiecał albo Los, że wiecznie

żyć będzie twoja żona,

słusznie mógłbyś bez przerwy opłakiwać zmarłą,

najdzielniejszy Januszu.

Kogo nie wzruszy stałość ducha niezachwiana

smutną klęską, pobożność,

wstydliwość, czułość z serca czystego płynąca,

skromność, królowa cnoty,

gorliwość czy na przyszłe rzeczy zważająca

przenikliwość umysłu?

Długiego jednak życia ludziom wielkiej cnoty

Los nie może obiecać;

dojrzałych nie mogą już niebiosa zostawić

dłużej na nędznej ziemi.

Nie zadręczaj ich długą skargą, gdy żądają

zwrotu wielkiego dobra,

ogromnych skarbów duszy, męstwa, złotą cnotą

nasyconego serca.

Tak Tanakwil, tak Klaudia dziewiczą odwagą

sprowadziła Kybele,

Tesalka w śmierci zastąpiła męża, Klelia

przypłynęła do Lacjum;

nawet przedwcześnie zmarłe żyć po śmierci mogą

wiecznie w pieśni poetów.

Choćbym nieczułe cienie mógł poruszyć pieśnią

Orfeuszowej lutni,

zamkniętych drzwi ze stali i spiżowych murów

niebios żona nie skruszy

i do ciebie nie wróci. Bram nie wzruszy żadna

prośba, żaden poeta.

Są w nich jednak niewielkie szczeliny dające

widzieć rzeczy ukryte.

Widziałem przez nie, skoro istnieć mogą cienie,

lub sądziłem, że widzę:

szła wielkim polem, które otaczał świetlisty

mur z jasnymi bramami. 
Złotem lśnią łąki, drzewa też stroją się w złoto,

błyszczą klejnoty fiołków;

nie ukaże ich piękno zwodnicze kryształu

czy farba Apellesa.

Tam wiele sławnych niewiast śpiewa nieustannie pieśni w pięknych dolinach.

Nad polem nowe gwiazdy i promienne światła ognistym świecą blaskiem.

Ona przez środek pola z wnukiem, pełna życia,

o różanym obliczu,

szła z uśmiechem na ustach, splatając dla siebie

i wnuka wieniec $\mathrm{z}$ kwiatów.

Mgła o wielkiej jasności nie dała mi więcej

ujrzeć śmiertelnym okiem.

Nie chciej więcej. Wystarczy, gdy ulotną chwilę

Los zmienił komuś w wieczność.

\section{Objaśnienia}

w. 2: aeternos annos - por. Ps 77(76),6: „cogitavi dies antiquos et annos aeternos in mente habui”, „rozważam dni starodawne i lata poprzednie wspominam” (wszystkie cytaty $z$ Wulgaty za edycją: The Vulgate Bible, vol. 3: The Poetical Books, ed. by S. Edgar, A.M. Kinney, Cambridge (MA) 2011).

w. 3: per assiduos [...] fletus - por. Katullus, Carm. 68, 55-56: „maesta neque assiduo tabescere lumina fletu / cessarent”, „smutne oczy nie przestawały rozpływać się w ciągłym płaczu"; Katullus, Poezje wszystkie, przeł. G. Franczak, A. Klęczar, wstęp A. Klęczar, indeksy metryczne K. Woś, Kraków 2013 (przekład zmieniono).

w. 4: ereptam - Barbara z Naruszewiczów (1580-18 VII 1627), córka Stanisława Naruszewicza i Elżbiety (Halszki) Komajewskiej; w 1595 roku poślubiła Janusza Skumina Tyszkiewicza. Małżeństwo doczekało się jednej córki, Katarzyny Eugenii (ok. 16101646), która dwa miesiące po śmierci matki, 19 września 1627 roku, wyszła w Wilnie za mąż za księcia Janusza Wiśniowieckiego (1599-1636), starostę krzemienieckiego.

w. 4: $\quad$ Ianussi - Janusz Skumin Tyszkiewicz (1572-1642), syn Teodora Tyszkiewicza i Katarzyny Lackiej, starosta jurborski, nowowolski, brasławski (1588-1626), pisarz wielki litewski (1607), wojewoda trocki (1626-1640), wojewoda wileński (1640-1642), dyplomata na dworze Zygmunta III Wazy. Studiował w Bazylei i Padwie. Pozostawił diariusz z podróży do Szwecji w 1625 roku. Jako unita wspierał wileńską cerkiew św. Trójcy i działający przy niej zakon bazylianów. Kazanie na pogrzebie Tyszkiewicza (24 października 1642) wygłosił Aleksander Dubowicz (Wyprawienie osoby, która od Boga wzią i na theatrum świata szczesśliwie odprawił Jaśnie Wielmożny Jego Mość Pan Janusz Skumin Tyszkiewicz, wojewoda wileński, brasławski, jurborski, nowowolski etc. starosta, [Vilnius 1642]). 
w. 5: quem non moveat - por. Cyceron, De div. I 40: „Quis est autem, quem non moveat clarissimis monumentis testata consignataque antiquitas?”, „Czy jest więc ktoś, kogo nie wzruszy poświadczona i potwierdzona najsłynniejszymi pomnikami starożytność?" (Cicero, On Old Age, On Frienship, On Divination, transl. by W.A. Falconer, Cambridge (MA) 1923).

w. 15: longis onerare querelis - por. Seneka, Ep. 78, 13: „Noli mala tua facere tibi ipse graviora et te querelis onerare: levis est dolor si nihil illi opinio adiecerit”, „Nie czyń swoich nieszczęść jeszcze większymi i nie obciążaj się skargami: ból jest łagodny, jeśli mniemanie niczego mu nie dodaje" (Seneca, Epistles, vol. 2: Epistles 66-92, transl. by R.M. Gummere, Cambridge (MA) 1920).

w. 18: incoctum bene pectus honesto - por. Persjusz, Sat. 2, 74: „et incoctum generoso pectus honesto”, ,i serce napełnione szlachetną hojnością” (Juvenal, Persius, Juvenal and Persius, ed. and transl. by S.M. Braund, Cambridge (MA) 2004).

w. 19: Tanaquil - Tanakwil, żona piątego króla Rzymu, Tarkwiniusza Starego, która pochodziła z wpływowego rodu etruskiego; potrafiła przepowiadać przyszłość. Ogniste płomienie wokół głowy śpiącego Serwiusza Tulliusza odczytała jako zapowiedź objęcia przezeń władzy królewskiej (Liwiusz, Ab Urbe, I 39, 1-3). Według innych przekazów, kiedy przybyła do Rzymu, przyjęła imię Gaja Cecylia (Gaia Caecilia). Stała się wzorem cnót rzymskiej matrony, zwłaszcza prostoty życia i wierności tradycji. Por. Klaudian, Laus Serenae, 15-16: „Latiis movet ora Camenis / praescia fatorum Tanaquil”, „dzięki łacińskim Muzom Tanakwil przepowiada przyszłe zdarzenia" (wszystkie oryginalne cytaty z Klaudiana za edycją: Claudian, On Stilicho's Consulship 2-3, Panegyric on the Sixth Consulship of Honorius, The Gothic War, Shorter Poems, Rape of Proserpina, transl. by M. Platnauer, Cambridge (MA) 1922).

w. 19-20: Claudia - Klaudia Kwinta odegrała dużą rolę w sprowadzeniu posągu Kybele (Wielkiej Matki, Matki Bogów), frygijskiej bogini płodności i urodzaju, do Rzymu. Kiedy okręt wiozący statuę osiadł na mieliźnie u ujścia Tybru, Klaudia zaniosła modlitwy do bogini, chwyciła linę i przyciągnęła go do brzegu. To cudowne zdarzenie uznano za dowód jej cnotliwości, por. Owidiusz, Fasti IV, 305-344. Por. Klaudian, Laus Serenae, 17-18: „et eodem flumine ducens / Claudia virgineo cunctantem crine Cybeben”, „i Klaudia ciągnąca w tej samej rzece [Tybrze] dziewiczym warkoczem ociągającą się Kybele".

w. 21: Thessala - Alcestis ('A $\lambda \kappa \eta \sigma \tau \iota)$ ), córka Peliasa i Anaksibii, żona Admeta z Feraj, króla Tesalii; wzór miłości małżeńskiej. Zgodziła się umrzeć za męża, ale pod warunkiem, że nie ożeni się on po jej śmierci z inną kobietą. Główna bohaterka tragikomedii Eurypidesa (Alkestis); fragment pierwszego aktu (w. 1-85) tego utworu przełożył Jan Kochanowski (Alcestis męża od śmierci zastąiła). U Sarbiewskiego wierne powtórzenie słów z utworu Klaudiana, Laus Serenae, 12-14: „quod sponte redempto / casta maritali successit Thessala fato / inque suos migrare virum non abnuit annos”, „pobożna Tesalka dobrowolnie wybawiła męża od śmierci i nie odmówiła mu oddania swoich lat życia”.

w. 22: Cloelia - Klelia wraz z dziesięcioma dziewczętami była zakładniczką etruskiego króla, Porsenny (507 r. p.n.e.), którego wojska oblegały Rzym. Namówiła je do ucieczki. 
Udało im się przepłynąć wody Tybru i dotrzeć do Rzymian. Oni jednak wydali Klelię Porsennie. Tym razem władca obdarzył ją wolnością. Stała się wzorem nieustraszonej, walecznej dziewicy (virago), por. Liwiusz, Ab Urbe II 13, 6-11; Wergiliusz, Aen. VIII, 651: „et fluvium vinclis innaret Cloelia ruptis”, „Klelia, zerwawszy więzy, przepłynęła rzekę" (wszystkie oryginalne cytaty z Eneidy za edycją: Virgil, Aeneid: Books 7-12, Appendix Vergiliana, transl. by H.R. Fairclough, rev. by G.P. Goold, Cambridge (MA) 1918); Klaudian, Laus Serenae, 16-17: „rediensque per undas / Cloelia Thybrinas”, „Klelia powracająca przez wody Tybru”.

w. 23: ante diem raptae - por. Wergiliusz, Aen. IV, 697: „sed misera ante diem subitoque accensa furore”, „lecz [Dydona] nieszczęsna [umierała] przedwcześnie nagłym obłędem owładnięta" (Virgil, Eclogues, Georgics, Aeneid: Books 1-6, transl. by H.R. Fairclough, rev. by G.P. Goold, Cambridge (MA) 1916).

w. 28: Elysii pomoeria muri - obraz mitycznego Elizjum (Pól Elizejskich) łączy się tu z wyobrażeniem rajskiego ogrodu i „niebiańskiego Jeruzalem”, por. Sarbievius, Lyr. IV 21, 1-2: „Fallor? An Elysii laeva de parte sereni / me mea vita vocat?”, „Czy się mylę? Czy z lewej strony jasnych niebios woła mnie już mój miły?”.

w. 34: aut vidi, aut vidisse putavi - por. Owidiusz, Her. X, 31: , aut vidi, aut fuerant quae me vidisse putarem”, „[mówi Ariadna] widziałam albo zdawało mi się, że widziałam”; Her. XVIII, 32: „aut videt, aut acies nostra videre putat”, „widzi albo sądzi, że widzi na własne oczy" (Ovid, Heroides, Amores, transl. by G. Showerman, rev. by G.P. Goold, Cambridge (MA) 1914); Wergiliusz, Aen. VI, 454: „aut videt, aut vidisse putat per nubila Lunam”, „ujrzał albo sądził, że ujrzał księżyc wschodzący wśród chmur”.

w. 36: stant moenia - por. Klaudian, Rapt. Pros. 238-239: „stant ardua ferro / moenia, ferrati postes, immensaque nectit / claustra chalybs”, [opis pałacu Ceres] „niedostępne mury z żelaza, żelazne bramy, stalowa krata zamyka potężną twierdzę”; Ap 21,18: „et erat structura muri eius ex lapide iaspide ipsa vero civitas auro mundo simile vitro mundo”, „a mur jego jest zbudowany z jaspisu, a Miasto - to szczere złoto do szkła czystego podobne".

w. 37: arbor crinitur in aurum - por. Stacjusz, Sil. IV 5, 9-10: „nunc cuncta veris frondibus annuis / crinitur arbos”, „teraz wszystkie drzewa okrywają się corocznymi liśćmi” (Statius, Silvae, ed. and transl. by D.R. Shackleton Bailey, rev. by Ch.A. Parrott, Cambridge (MA) 2015).

w. 46: roseo vivacior ore - utarte wyrażenie, por. Wergiliusz, Aen. II, 593: „roseoque haec insuper addidit ore”, „i to powiedziała [Wenus] różanymi ustami”, Aen. IX, 5: „ad quem sic roseo Thaumantias ore locuta est”, „tak do niego [Turnusa] przemówiła różanymi ustami Taumantyda [córka Taumasa, czyli Iris]"; Owidiusz, Met. VII, 45: "quod sit roseo spectabilis ore”, „[Aurora] jest godna podziwu dzięki różanemu obliczu” (Ovid, Metamorphoses, vol. 1: Books 1-8, transl. by F.J. Miller, rev. by G.P. Goold, Cambridge (MA) 1916).

w. 47: ibat ovans - por. Wergiliusz, Aen. VI, 588-590: „per Graium populos mediaeque per Elidis urbem, / ibat ovans divumque sibi poscebat honorem; demens", [mowa o Salmoneusie] „jechał z radością wśród greckich ludów przez środek Elidy i domagał się dla siebie boskiej czci, szalony". 
w. 49-50: caligo... mortali percurrere visu - por. Wergiliusz, Aen. II, 604-606: „aspice, namque omnem, quae nunc obducta tuenti / mortales habetat visus tibi et humida circum / caligat nubem eripiam”, „spójrz [mówi Wenus do Eneasza], gdyż ja tę gęstą chmurę, która rozpostarta zaciemnia teraz twój wzrok śmiertelny, rozproszę".

w. 51: Satis est, cui fata dederunt - por. Horacy, Ep. I 2, 46: „quod satis est cui contingit, nihil amplius optet”, „kto ma wystarczająco, czego potrzeba, niech więcej niczego nie pragnie”; Carm. IV 13, 22-23: „,sed Cynarae breves / annos fata dederunt”, „lecz Los dał Cynarze krótkie lata życia" (Horace, Satires, Epistles, The Art of Poetry, transl. by H.R. Fairclough, Cambridge (MA) 1926).

\section{Bibliografia}

\section{Źródła}

Cicero, On Old Age, On Frienship, On Divination, transl. by W.A. Falconer, Cambridge (MA) 1923. Claudian, On Stilicho's Consulship 2-3, Panegyric on the Sixth Consulship of Honorius, The Gothic War, Shorter Poems, Rape of Proserpina, transl. by M. Platnauer, Cambridge (MA) 1922.

Droczyłowski E., Dextera. Fidei constantiaeque testis [...], Vilnius, Typis Academicis Societatis Iesu, 1620.

Dubowicz J., Kazanie na pogrzebie Jaśnie Wielmożnej Paniej, Jej M[ości] Paniej Barbary Naruszewiczówny, Januszowej Skuminowej Tyszkiewiczowej, wojewodzinej trockiej, jurborskiej, nowowolskiej etc. starościnej. Miane w cerkwi wileńskiej Trójce Przenaświętszej 2 dnia września roku $P$ [ańskiego] 1627, [Vilnius 1627].

Horace, Satires, Epistles, The Art of Poetry, transl. by H.R. Fairclough, Cambridge (MA) 1926.

Juvenal, Persius, Juvenal and Persius, ed. and transl. by S.M. Braund, Cambridge (MA) 2004. Katullus, Poezje wszystkie, przeł. G. Franczak, A. Klęczar, wstęp A. Klęczar, indeksy metryczne K. Woś, Kraków 2013.

Marracci H., Bibliotheca Mariana alphabetico ordine digesta, t. II, Roma: Francesco Cavalli, 1648. Oda Sarbiewskiego do Janusza Skumina Tyszkiewicza, wojewody trockiego, w dzień pogrzebu swojej małżonki, tłum. A. Naruszewicz, „Zabawy Przyjemne i Pożyteczne” 5 (1772), cz. 2, s. 401-405.

Ovid, Heroides, Amores, transl. by G. Showerman, rev. by G.P. Goold, Cambridge (MA) 1914.

Ovid, Metamorphoses, vol. 1: Books 1-8, transl. by F.J. Miller, rev. by G.P. Goold, Cambridge (MA) 1916.

Pismo Święte Starego i Nowego Testamentu w przekładzie z języków oryginalnych [Biblia Tysiąclecia], oprac. zespół biblistów polskich z inicjatywy benedyktynów tynieckich, wyd. 5, Poznań 1999.

Radziwiłł A.S., Pamiętnik o dziejach w Polsce, t. 1: 1632-1636, przeł. i oprac. A. Przyboś, R. Żelewski, Warszawa 1980.

Sarbievius M.C., Lyricorum libri quattuor, epodon liber unus alterque epigrammatum, Antwerpen: Officina Plantiniana Balthasaris Moreti, 1632. 
Sarbievius M.C., Lyricorum libri quattuor, epodon liber unus alterque epigrammatum, Antwerpen: Officina Plantiniana Balthasaris Moreti, 1634.

Sarbievius M.C., Lyricorum libri tres, epigrammatum liber unus, edita tertia auctior, Antwerpen: Johannes Cnobbar, 1630.

Sarbiewski M.C., Oratio panegyrica habita in praesentia Serenissimi ac Invictissimi Vladislai IV, Poloniae et Sueciae regis in solenni corporis divi Casimiri translatione priusquam publica processione per urbis Vilnae plateas in regium cathedralis templi sacelium deferretur. Anno 1636 14. Augusti, Vilnius: Typis Academicis Societatis Iesu, 1636.

Seneca, Epistles, vol. 2: Epistles 66-92, transl. by R.M. Gummere, Cambridge (MA) 1920.

Starowolski S., Monumenta Sarmatarum viam universae carnis ingressorum, Kraków: Vidua et haeredes Francisci Caesarii, 1655.

Statius, Silvae, ed. and transl. by D.R. Shackleton Bailey, rev. by Ch.A. Parrott, Cambridge (MA) 2015.

Virgil, Aeneid: Books 7-12, Appendix Vergiliana, transl. by H.R. Fairclough, rev. by G.P. Goold, Cambridge (MA) 1918.

Virgil, Eclogues, Georgics, Aeneid: Books 1-6, transl. by H.R. Fairclough, rev. by G.P. Goold, Cambridge (MA) 1916.

The Vulgate Bible, vol. 3: The Poetical Books, ed. by S. Edgar, A.M. Kinney, Cambridge (MA) 2011.

\section{Opracowania}

Budzyński J., Horacjanizm w liryce polsko-łacińskiej renesansu i baroku, Wrocław 1985.

Budzyński J., „Parodia” $i$ „palinodia” horacjańska w liryce M.K. Sarbiewskiego. Studium z techniki poezji barokowej, „Meander” 30 (1975), s. 88-108.

Buszewicz E., Oblicza pobożnej tęsknoty. Uwagi o istniejących i możliwych przekładach poezji Macieja Kazimierza Sarbiewskiego, „Ruch Literacki” 38 (1997), z. 4, s. 515-521.

Buszewicz E., Sarmacki Horacy i jego liryka. Imitacja - gatunek - styl. Rzecz o poezji Macieja Kazimierza Sarbiewskiego, Kraków 2006.

Davis G., Polyhymnia: The Rhetoric of Horatian Lyric Discourse, Berkeley 1991.

Fulińska A., Naśladowanie i twórczość. Renesansowe teorie imitacji, emulacji i przekładu, Wrocław 2000.

Hutcheon L., Ironia, satyra, parodia - o ironii w ujęciu pragmatycznym, przeł. K. Górska, „Pamiętnik Literacki” 77 (1986), z. 1, s. 331-350.

Khan A., Horace's Ode to Virgil on the Death of Quintilius: I.24, „Latomus” 26 (1967), s. 107-117.

Kolendo-Korczak K., Nagrobek Jerzego Rudominy i ośmiu towarzyszy polegtych w bitwie pod Chocimiem w 1621 roku, „Przegląd Wschodni” (2001), nr 27-29, s. 875-886.

Kubiak Z., Szkoła stylu. Eseje o tradycji poezji europejskiej, Warszawa 1972.

Kuran M., Druk Eustachego Droczyłowskiego z okazji zaręczyn Rakowskiego i Tyszkiewiczówny (U genezy „Księcia Wiśniowieckiego Janusza” Samuela Twardowskiego), „Akapit. Rocznik Towarzystwa Bibliofilów Polskich w Warszawie" 1 (2006), s. 11-20.

Kuran M., Mecenat kulturalny Janusza Skumina Tyszkiewicza. Aspekt wizualny druków naukowych i okolicznościowych, „Dailès Istorijos Studijos” 4 (2010), s. 69-104. 
Kuran M., Obraz i słowo w kazaniu Aleksandra Dubowicza pod tytułem Wyprawienie osoby... upamiętniajacym postać Janusza Skumina Tyszkiewicza, „Terminus” 14 (2012), z. 25, s. 119-135. Łukaszewicz-Chantry M., Raj chrześcijański na Polach Elizejskich. Analiza dwóch pieśni Macieja Kazimierza Sarbiewskiego, „Pamiętnik Literacki” 91 (2000), z. 1, s. 179-187.

Łukaszewicz-Chantry M., Trzy nieba. Przestrzeń sakralna w liryce Macieja Kazimierza Sarbiewskiego, Wrocław 2002.

Mikołajczak A.W., Antyk w twórczości Macieja Kazimierza Sarbiewskiego, Poznań 1994.

Putnam M.C.J., The Language of Horace Odes 1.24, „The Classical Journal” 88 (1993), no. 2, s. $123-135$.

Ryczek W., Retoryka marzenia sennego. Oda do Wojciecha Turskiego (IV. 32) Macieja Kazimierza Sarbiewskiego, „Teksty Drugie” (2016), nr 5, s. 74-96.

Sokolski J., Staropolskie zaświaty. Obraz piekła, czyśćca i nieba w renesansowej i barokowej literaturze polskiej wobec tradycji średniowiecznej, Wrocław 1994.

Stawecka K., Maciej Kazimierz Sarbiewski - prozaik i poeta, Lublin 1989.

Thibodeau Ph., Can Vergil Cry? Epicureanism in Horace Odes 1.24, „The Classical Journal” 98 (2003), no. 3, s. 243-256.

Thom S., "That No Man Lives Forever”: Horace on the Death of Quintilius (1.24), „Akroterion” 41 (1996), no. 3-4, s. 114-123.

Tyszkiewicz E., Groby rodziny Tyszkiewiczów, Warszawa 1873.

Urbański P., Theologia fabulosa. Commentationes Sarbievianae, Szczecin 2000.

Wichary G., Recepcja twórczości M.K. Sarbiewskiego w polskim Oświeceniu, „Pamiętnik Literacki" 66 (1975), z. 2, s. 143-157.

Zaborowska-Musiał J., Obraz miasta ziemskiego i niebiańskiego w Oratio in sollenni corporis divi Casimiri translatione habita Macieja Kazimierza Sarbiewskiego, „Meander” 70 (2015), s. $113-129$.

\section{WOJCIECH RYCZEK}

仓) Uniwersytet Jagielloński w Krakowie / Jagiellonian University in Kraków, Poland

@ wojtek.ryczek[at]interia.pl

(D) https://orcid.org/0000-0003-3288-1642

Wojciech Ryczek-Assistant Professor at the Department of Polish Studies at Jagiellonian University in Kraków. Research interests: history of rhetoric, modes of figuration, Neo-Latin literature, history of ideas, translation studies, anthropology. Recent publications: "Parodie horacjańskie. Przekład siedmiu pieśni Macieja Kazimierza Sarbiewskiego", Symbolae Philologorum Posnaniensium Graece et Latine 29 (2019), no. 2; "Speaking Freely: Keckermann on Figure of Parrhesia", Rhetorica 37 (2019), no 2. 